\title{
Correction to: A case report of left paraduodenal hernia with a spontaneous reduction on follow-up: the rare demonstration on computed tomography
}

Saurabh Maheshwari ${ }^{1 *}$, Ajay Khadka ${ }^{1}$, Saikat Bhattacharjee ${ }^{2}$, Uddandam Rajesh $^{1}$ and Vibhuti Maria ${ }^{3}$

\section{Correction to: Egypt J Radiol Nuclear Med 51, 224 (2020)} https://doi.org/10.1186/s43055-020-00338-4

Following publication of the original article [1], the authors identified an error in the affiliation. The correct affiliation of the authors 1,2, and 4 are given below.

Correct affiliation:

Department of Radiodiagnosis and Imaging, Armed Forces Medical College, Pune, India.

The author group has been updated above and the original article [1] has been corrected.

\footnotetext{
Author details

'Department of Radiodiagnosis and Imaging, Armed Forces Medical College, Pune, India. ${ }^{2}$ Radiodiagnosis and Imaging, Army Institute of Cardio-thoracic Sciences, Pune, India. ${ }^{3}$ Department of Ophthalmology, Armed Forces Medical College, Pune, India.
}

Published online: 10 December 2020

\section{Reference}

1. Maheshwari et al (2020) A case report of left paraduodenal hernia with a spontaneous reduction on follow-up: the rare demonstration on computed tomography. Egypt J Radiol Nuclear Med 51:224. https://doi.org/10.1186/ s43055-020-00338-4

\footnotetext{
The original article can be found online at https://doi.org/10.1186/s43055020-00338-4

* Correspondence: saurabhmhshwr@yahoo.co.in

'Department of Radiodiagnosis and Imaging, Armed Forces Medical College, Pune, India
}

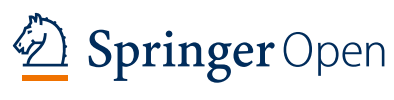

( ) The Author(s). 2020 Open Access This article is licensed under a Creative Commons Attribution 4.0 International License, which permits use, sharing, adaptation, distribution and reproduction in any medium or format, as long as you give appropriate credit to the original author(s) and the source, provide a link to the Creative Commons licence, and indicate if changes were made. The images or other third party material in this article are included in the article's Creative Commons licence, unless indicated otherwise in a credit line to the material. If material is not included in the article's Creative Commons licence and your intended use is not permitted by statutory regulation or exceeds the permitted use, you will need to obtain permission directly from the copyright holder. To view a copy of this licence, visit http://creativecommons.org/licenses/by/4.0/. 